\title{
A Coexisting Pilocytic Astrocytoma and a Prolactinoma: A Case Report of Collision Tumors and Literature Review
}

Antonia Malli ${ }^{1}$, Savvas Melissaris ${ }^{2}$, Anastasia Dimitriadi ${ }^{3}$, Theodosia Choreftaki ${ }^{3}$, Nikolaos Georgakoulias ${ }^{2}$

1. Department of Neurosurgery, The National and Kapodistrian University of Athens School of Health Sciences, Athens, GRC 2. Department of Neurosurgery, General Hospital of Athens "G. Gennimatas", Athens, GRC 3. Department of Pathology, General Hospital of Athens "G. Gennimatas", Athens, GRC

$\square$ Corresponding author: Antonia Malli, antoniamalli@hotmail.com

Disclosures can be found in Additional Information at the end of the article

\section{Abstract}

Pituitary adenomas and gliomas constitute two of the most common primary intracranial tumors. However, their coexistence as collision tumors is relatively rare and few similar reports could be identified in the literature. In this study, we report a case of a 64-year-old male patient with a prolactinoma and a pilocytic astrocytoma in collision. The patient underwent both an endoscopic transsphenoidal approach and a subfrontal craniotomy, achieving a gross total resection of the concomitant lesions in the sellar and suprasellar regions. Postoperatively, the patient's preoperative bitemporal hemianopsia resolved and no new deficits occurred. At his six-month follow-up, he remained free of neurologic deficits. Although causative factors are yet to be determined for these tumors in collision, their nonsyndromic coexistence could point to a common genetic linkage which will help to shed light on their natural history of occurrence.

Categories: Endocrinology/Diabetes/Metabolism, Neurosurgery, Oncology

Keywords: collision tumors, prolactinoma, pilocytic astrocytoma

\section{Introduction}

Pilocytic astrocytomas account for $5.4 \%$ of all gliomas, with an incidence much higher in the pediatric population [1]. In general, pilocytic astrocytomas typically correspond to the World Health Organization (WHO) Grade I tumour, arising both in the supratentorial and infratentorial regions [1]. Pituitary adenomas are one of the most common lesions in the sellar area, and they are generally classified into functioning and nonfunctioning neoplasms.

Received 04/08/2019

Review began 04/30/2019 Review ended 06/13/2019 Published 06/17/2019

(c) Copyright 2019

Malli et al. This is an open access article distributed under the terms of the Creative Commons Attribution License CC-BY 3.0., which permits unrestricted use, distribution, and reproduction in any medium, provided the original author and source are credited.
Lactotrophic tumors (prolactinomas) constitute the most prevalent secreting pituitary adenomas [2-3]. The coexistence of distinct primary neoplastic entities in the same intracranial region is generally defined as tumors in collision [4-5]. The collision of pituitary adenomas and gliomas has been previously reported in the existing literature [6-9]. However, to our best of knowledge, this is the first study to identify the coexistence of a prolactinoma and a pilocytic astrocytoma and their potential common pathogenetic mechanism.

\section{Case Presentation}

A 64-year-old male presented in our Neurosurgery Department with a 12-month history of visual disturbances, including bitemporal hemianopia. No history of prior radiation, chemical substance exposure, or associated familial tumor syndromes were reported. Magnetic resonance imaging (MRI) showed a suprasellar, not well-delineated tumor (36 x 29 x 25 mm in 


\section{Cureus}

diameter) with both cystic and solid components, which expanded into the third ventricle and had a heterogeneous enhancement in its periphery (Figure 1). The tumor pressed against the optic chiasm and surrounded the A1 segment of the right anterior cerebral artery. There was also another lesion located in the left part of the adenohypophysis with a maximum diameter of $12 \mathrm{~mm}$. Upon laboratory testing, serum prolactin levels were significantly increased above normal at $313 \mathrm{ng} / \mathrm{dl}$ (normal range up to $5 \mathrm{ng} / \mathrm{dl}$ ), and thus, he was treated with cabergoline, which only led to a minimal clinical improvement of the patient. Surgical intervention was then considered as the best treatment approach. Subsequently, both an endoscopic transsphenoidal approach and a subfrontal craniotomy were performed, achieving gross total resection of the lesions located in the sellar, the suprasellar, and hypothalamic regions.

Histology of the sellar lesion revealed a pituitary adenoma with positive immunohistochemistry for prolactin, whereas the suprasellar/hypothalamic part of the tumour was histologically identified as a pilocytic astrocytoma (Figure 2). Postoperatively, the patient had no visual loss and thus improved neurologically with no neurologic deficit. At six months follow-up, he was symptom-free.

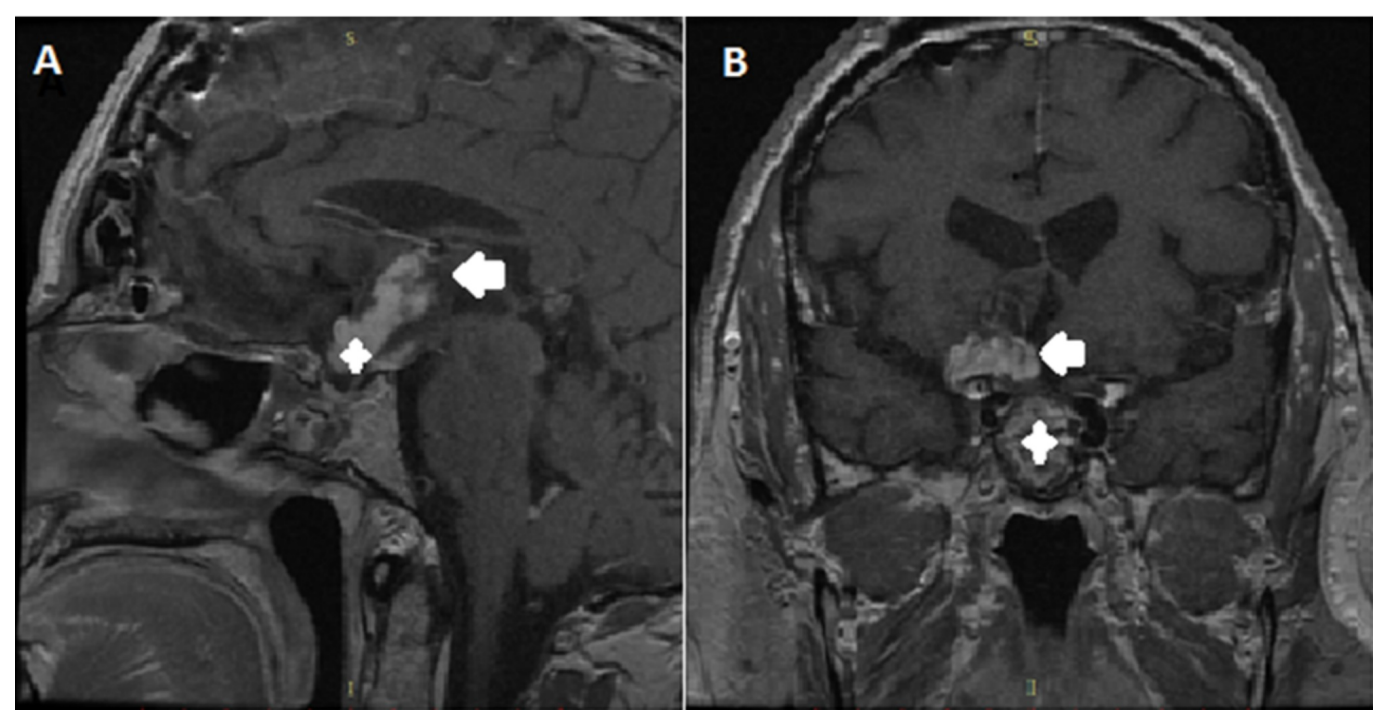

FIGURE 1: Preoperative magnetic resonance imaging (MRI) of the brain

(A) Sagittal contrast-enhanced T1-weighted image showing a heterogeneously enhancing mass in the sellar (white cross), suprasellar, and hypothalamic (white arrow) regions; (B) coronal contrastenhanced T1-weighted scan demonstrating two different heterogeneous lesions with cystic components in the sellar (white cross), suprasellar, and hypothalamic (white arrow) regions. 


\section{Cureus}
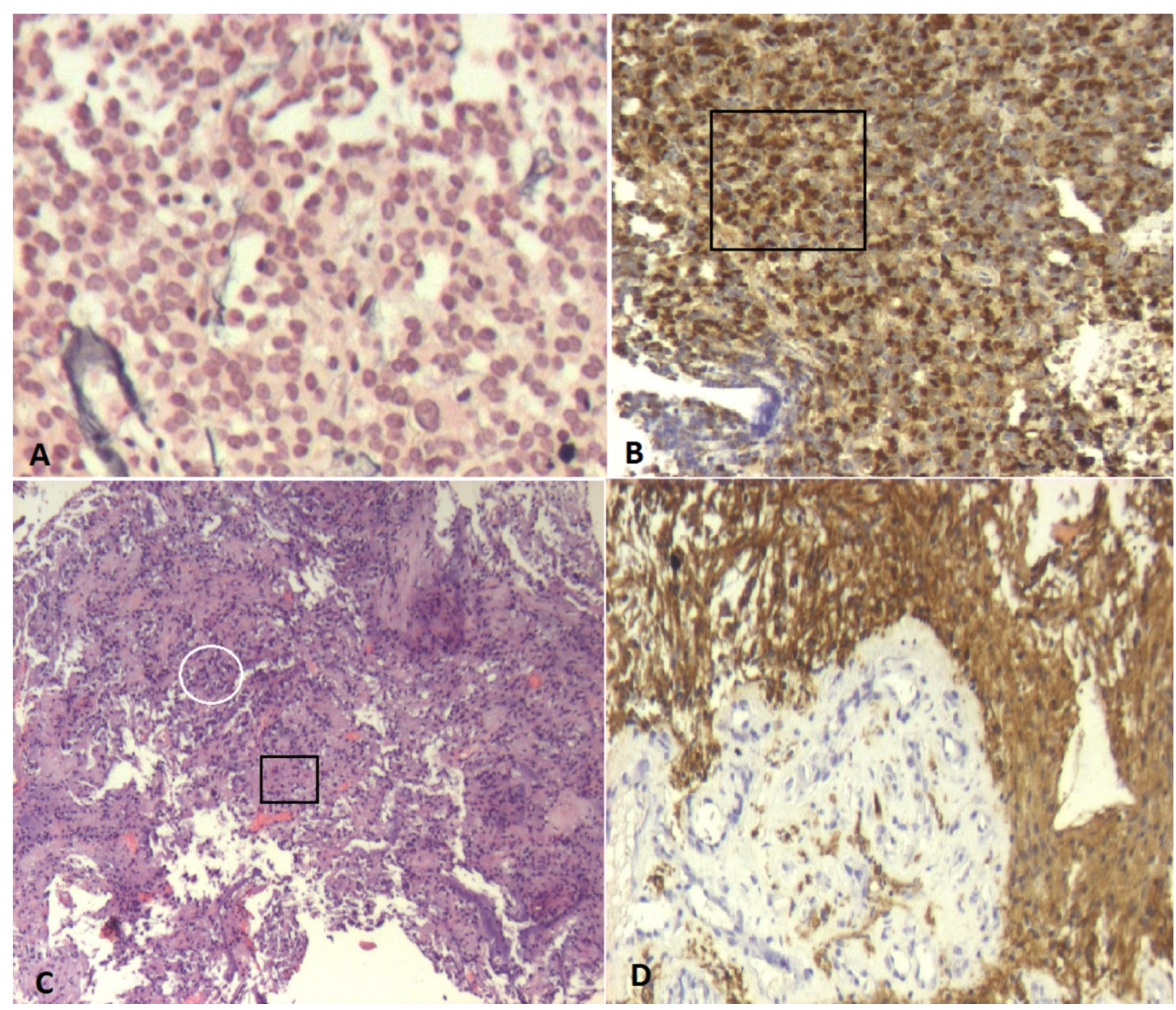

\section{FIGURE 2: Histopathological examination after surgical resection}

(A) Histochemistry shows a pituitary adenoma, reticulin staining, which shows a distortion in the reticulin network (x100); (B) immunohistochemistry shows positive staining for prolactin (black frame, $\mathrm{x} 100$ ); (C) hematoxylin-eosin staining reveals an astrocytic tumor of low (black frame) to moderate (white circle) cellularity with a biphasic pattern as seen in pilocytic astrocytomas (x50); (D) positive immunohistochemical staining for glial fibrillary acidic protein (GFAP, x100).

\section{Discussion}

Pituitary adenomas and astrocytomas in collision are a very rare occurrence reported in the current literature (Table 1). Our search in PubMed Central (PMC) and Google Scholar revealed no other case of a prolactinoma and a pilocytic astrocytoma coexisting in the same intracranial area. To our knowledge, this is the first study that describes such a combination of neoplasms. 


\section{Cureus}

\begin{tabular}{|c|c|c|c|}
\hline Study & Sex,Age & Tumor & Treatment \\
\hline $\begin{array}{l}\text { Naik et al. } \\
{[6]}\end{array}$ & $\begin{array}{l}\text { Male, } 36 \\
\text { years old }\end{array}$ & $\begin{array}{l}\text { Pituitary macroadenoma; anaplastic } \\
\text { astrocytoma }\end{array}$ & $\begin{array}{l}\text { Gross total resection via modified pterional } \\
\text { craniotomy }\end{array}$ \\
\hline $\begin{array}{l}\text { Jaiswal et } \\
\text { al. [7] }\end{array}$ & $\begin{array}{l}\text { Female, } 48 \\
\text { years old }\end{array}$ & $\begin{array}{l}\text { Ossifying pituitary adenoma; low- } \\
\text { grade astrocytoma }\end{array}$ & $\begin{array}{l}\text { Gross total resection via left frontotemporal } \\
\text { craniotomy }\end{array}$ \\
\hline $\begin{array}{l}\text { Furtado et } \\
\text { al. [8] }\end{array}$ & $\begin{array}{l}\text { Male, } 35 \\
\text { years old }\end{array}$ & $\begin{array}{l}\text { Thyrotropin-secreting pituitary } \\
\text { adenoma; low-grade astrocytoma }\end{array}$ & $\begin{array}{l}\text { Gross total resection via transsphenoidal endoscopic } \\
\text { surgery and right frontal craniotomy }\end{array}$ \\
\hline $\begin{array}{l}\text { Ezura et al. } \\
\text { [9] }\end{array}$ & $\begin{array}{l}\text { Male, } 33 \\
\text { years old }\end{array}$ & $\begin{array}{l}\text { Pituitary adenoma (chromophobe); } \\
\text { anaplastic astrocytoma }\end{array}$ & Gross total resection* \\
\hline
\end{tabular}

\section{TABLE 1: Literature Review for the Coexistence of Pituitary Adenomas and}

Astrocytomas

*information on the type of surgery was not available

The pathogenesis of prolactinoma and pilocytic astrocytoma in collision still remains undefined. However, several hypotheses could be valid. (1) This co-existence as a single event could be a coincidence of two common brain neoplasms. (2) Abnormalities in the BRAF gene and its signaling mitogen-activated protein kinase (MAPK) pathway have been identified as the most prominent molecular changes occurring in pilocytic astrocytomas [1]. However, the Nmyc downstream-regulated gene 2 (NDRG2), known as a tumor suppressor gene, could serve as a common pathogenetic factor for prolactinomas and pilocytic astrocytomas. In general, NDRG2 is located at chromosome 14q11.2. Skiriute et al. revealed that NDRG2 expression increased in glial cells in Grade I or II astrocytomas, while its expression was significantly decreased in higher grades [10]. Moreover, the latest evidence shows a promising genetic association between prolactinomas and the NDRG2 gene. The study by Vaitkiene et al. presented a higher expression of the NDRG2 gene in prolactinomas compared to all the other types of both functioning and non-functioning pituitary adenomas [11]. (3) Recent studies have shown that steroid hormones, especially estrogens, may play an essential role in the development and growth of human astrocytes [12-13]. It is well known that the majority of the estrogen effects are mediated by two types of nuclear receptors and transcriptional factors, ER $\alpha$ and ER $\beta$. Although highly homologous, ER $\alpha$ and ER $\beta$ are encoded by separate genes located on chromosome 6q25.1 and 14q22-24, respectively [12]. Studies have shown that estradiolmediated activation of ER $\alpha$, as well as the recruitment of steroid receptor coactivators (SRC-1 and SRC-3), led to astrocytoma growth [13-15]. Moreover, other studies have demonstrated increased expression of ER $\alpha$ in prolactinomas, a phenomenon which could possibly promote tumorigenesis by mediating autocrine or paracrine actions of the basic fibroblast growth factor (bFGF) and vascular endothelial growth factor (VEGF) [16-18].

Another key concept seen in vitro and in vivo is the expression of the pituitary tumor transforming gene (PTTG) induced by estrogens and bFGF, enabling the proliferation of lactotrophs and tumor formation [16, 18]. The presence of increased ER $\alpha$ in both prolactinomas and pilocytic astrocytomas could be attributed to a common pathogenetic substrate that will help shed light on the pathophysiology of two seemingly unrelated tumors. This mechanism will also highlight new therapeutic strategies, such as estrogen receptor antagonists as part of the nonoperative management. Thus, primary studies need to be conducted in an experimental 
and clinical setting in order to assess the validity of the hypothesis of a common genetic linkage.

\section{Conclusions}

Collision tumors consisting of a prolactinoma and a pilocytic astrocytoma are a rare phenomenon. While no causative factors can be derived from a single case report, we propose that potential mechanisms of this phenomenon are both ER $\alpha$-induced and NDRG2-mediated proliferation of both astrocytes and lactotrophs.

\section{Additional Information}

\section{Disclosures}

Human subjects: Consent was obtained by all participants in this study. Conflicts of interest: In compliance with the ICMJE uniform disclosure form, all authors declare the following: Payment/services info: All authors have declared that no financial support was received from any organization for the submitted work. Financial relationships: All authors have declared that they have no financial relationships at present or within the previous three years with any organizations that might have an interest in the submitted work. Other relationships: All authors have declared that there are no other relationships or activities that could appear to have influenced the submitted work.

\section{References}

1. Collins VP, Jones DT, Giannini C: Pilocytic astrocytoma: pathology, molecular mechanisms and markers. Acta Neuropathol. 2015, 129:775-88. 10.1007/s00401-015-1410-7

2. Seltzer J, Scotton TC, Kang K, Zada G, Carmichael JD: Gene expression in prolactinomas: a systematic review. Pituitary. 2016, 19:93-104. 10.1007/s11102-015-0674-1

3. Bi WL, Horowitz P, Greenwald NF, et al.: Landscape of genomic alterations in pituitary adenomas. Clin Cancer Res. 2017, 23:1841-51. 10.1158/1078-0432.CCR-16-0790

4. Gkekas N, Georgakoulias N, Kakiopoulos G, Seretis A: De novo intracranial collision tumour in previously evacuated intracerebral haematoma site. Br J Neurosurg. 2012, 26:880-81.

10.3109/02688697.2012.697220

5. Mitsos AP, Konstantinou EA, Fotis TG, Lafazanos SA, Kontogeorgos G, Georgakoulias NV: Sphenoid wing meningioma and glioblastoma multiforme in collision - case report and review of the literature. Neurol Neurochir Pol. 2009, 43:479-83.

6. Naik H, Vernon V, Gade P, Bhople L, Guha A: Anaplastic astrocytoma and pituitary macroadenoma within the same patient: a rare case of intracranial collision tumor. Neurol India. 2018, 66:857-60. 10.4103/0028-3886.232341

7. Jaiswal S, Vij M, Jaiswal AK, Chand G, Behari S, Kumarjain V: Ossifying pituitary adenoma coexisting with astrocytoma and pituitary adenoma associated with gangliocytoma: two unusual conditions. Turk Neurosurg. 2012, 22:127-33. 10.5137/1019-5149.JTN.3398-10.0

8. Furtado SV, Dadlani R, Ghosal N, Mahadevan A, Shankar SK, Hegde AS: Co-existing thyrotropin secreting pituitary adenoma and low grade glioma: clinical considerations and literature review. J Neurosurg Sci. 2009, 53:71-75.

9. Ezura M, Kayama T, Sakurai Y, Ogawa A, Wada T: A case of anaplastic astrocytoma associated with pituitary adenoma (Article in Japanese). No Shinkei Geka. 1988, 16:1505-509.

10. Skiriutė D, Steponaitis G, Vaitkienė P, Mikučiūnas M, Skauminas K, Tamašauskas A, Kazlauskas A: Glioma malignancy-dependent NDRG2 gene methylation and downregulation correlates with poor patient outcome. J Cancer. 2014, 5:446-56. 10.7150/jca.9140

11. Vaitkiene P, Valiulyte I, Glebauskiene B, Liutkeviciene R: N-myc downstream-regulated gene 2 (NDRG2) promoter methylation and expression in pituitary adenoma. Diagn Pathol. 2017, 12:33. 10.1186/s13000-017-0622-7

12. Tavares CB, Gomes-Braga FC, Costa-Silva DR, et al.: Expression of estrogen and progesterone receptors in astrocytomas: a literature review. Clinics (Sao Paulo). 2016, 71:481-86.

13. González-Arenas A, Hansberg-Pastor V, Hernández-Hernández OT, et al.: Estradiol increases 


\section{Cureus}

cell growth in human astrocytoma cell lines through $\mathrm{ER} \alpha$ activation and its interaction with SRC-1 and SRC-3 coactivators. Biochim Biophys Acta. 2012, 1823:379-86.

10.1016/j.bbamcr.2011.11.004

14. Hernández-Hernández OT, González-García TK, Camacho-Arroyo I: Progesterone receptor and SRC-1 participate in the regulation of VEGF, EGFR and Cyclin D1 expression in human astrocytoma cell lines. J Steroid Biochem Mol Biol. 2012, 132:127-34.

10.1016/j.jsbmb.2012.04.005

15. Liu C, Zhang Y, Zhang K, Bian C, Zhao Y, Zhang J: Expression of estrogen receptors, androgen receptor and steroid receptor coactivator-3 is negatively correlated to the differentiation of astrocytic tumors. Cancer Epidemiol. 2014, 38:291-97. 10.1016/j.canep.2014.03.001

16. Lv H, Li C, Gui S, Zhang Y: Expression of estrogen receptor $\alpha$ and growth factors in human prolactinoma and its correlation with clinical features and gender. J Endocrinol Invest. 2012, 35:174-80.

17. Scully KM, Gleiberman AS, Lindzey J, Lubahn DB, Korach KS, Rosenfeld MG: Role of estrogen receptor-alpha in the anterior pituitary gland. Mol Endocrinol. 1997, 11:674-81. 10.1210/mend.11.6.0019

18. Heaney AP, Fernando M, Melmed S: Functional role of estrogen in pituitary tumor pathogenesis. J Clin Invest. 2002, 109:277-83. 10.1172/JCI200214264 